\title{
The Effect of Learning Model and Interpersonal Intelligence on Economic Learning Outcomes of Class X Dwiwarna Students High School
}

\author{
Ernita $^{1}$, Edward Purba ${ }^{2}$ and Abdul Hasan Saragih ${ }^{3}$ \\ Postgraduate Scholar ${ }^{1-2}$ and Professor ${ }^{3}$ \\ Department of Education Technology \\ State University of Medan \\ Medan, North Sumatera \\ Indonesia
}

\begin{abstract}
This study aims to determine the learning ability of Economics subjects with a higher Quantum Teaching learning model than that taught by the Inquiry-Based Learning model. The second objective is the ability to study Economics subjects who have high interpersonal intelligence and low interpersonal intelligence. The populations in this study were students at the Dwiwarna High School. The research sample was taken 2 classes namely class X-1 and class X-2. The results of this study are: (1) Economic learning abilities of students taught with Quantum Teaching learning models are higher than those taught by Inquiry-Based Learning models. This can be seen from the analysis of the data obtained where the value of $F_{\text {count }}=5.01$ while the value of $F_{\text {table }}$ $=4.01$ so that $F_{\text {count }}>F_{\text {table }}$. (2) Economic learning ability that has high interpersonal intelligence is higher than the Economic learning ability of students who have low interpersonal intelligence. This can be seen from the analysis of the data obtained where the value of $F_{\text {count }}=4.88$ while the value of $F_{\text {table }}=4.01$ so that $F_{\text {count }}>F_{\text {table }}$.
\end{abstract}

Key Words: Quantum Teaching, Intelligence Interpersonal, Economics, Learning Model.

\section{INTRODUCTION}

Economic lessons are one of the main subjects taught starting from the level of junior high school to university and also one of the subjects tested in the National Examination at the high school level. Besides that, economics is also a fundamental knowledge which includes aspects of conceptual understanding, reasoning and communication, and aspects of problem solving that are very much needed in technological development.

Based on the competency standards of high school graduates as well as the objectives of economic subjects described previously, each student should have a number of abilities to apply economic concepts in daily life, especially in the environment of individuals, households, communities and countries.

Low value Student economy is a problem faced today, where the success of students in following a lesson can be seen from the results obtained. Based on the author's interview with the economics teacher at the Dwiwarna High School in Medan, the problem faced by students in economic learning is the lack of enthusiasm of students during learning. Students are more likely to accept whatever is conveyed by the teacher, silent and reluctant to express questions or opinions. Data on students' economic learning outcomes have not shown optimal results so far with a minimum of 75 (seventy five) Economic Completion Criteria. This can be seen in the learning outcomes of the Semester Final Exams in economic class X in the Medan Dwiwarna High School for Academic Year 2014 until 2017 in Table 1. 
International Journal of Advances in Scientific Research and Engineering (ijasre), Vol 5 (1), January-2019

Table 1. Final Semester Exam Results Economics Class X Dwiwarna High School 2014 until 2017

\begin{tabular}{|l|c|c|c|c|}
\hline School Year & $\begin{array}{c}\text { Minimum Completion } \\
\text { Criteria Value }\end{array}$ & $\begin{array}{c}\text { Lowest } \\
\text { Value }\end{array}$ & $\begin{array}{c}\text { The } \\
\text { Highest } \\
\text { Score }\end{array}$ & $\begin{array}{c}\text { Average } \\
\text { Value }\end{array}$ \\
\hline $\mathbf{2 0 1 4 - 2 0 1 5}$ & 75 & 58 & 83 & 71 \\
\hline $\mathbf{2 0 1 5 - 2 0 1 6}$ & 75 & 62 & 87 & 75 \\
\hline $\mathbf{2 0 1 6 - 2 0 1 7}$ & 75 & 67 & 89 & 78 \\
\hline
\end{tabular}

Learning model quantum (quantum teaching) is one of the learning model who develop a learning environment that empowers each other, respects and always maintains learning motivation. In this learning requires students to be directly involved in understanding the concept and constructing their knowledge to solve problems so that an adequate understanding of the concept is achieved.

In addition, an important factor determining the success of learning is the characteristics of students, namely the background of students, Intelligence is one of the internal factors and as the main factor that determines the success of the failure of students to learn. Gardner has the view that intelligence is not something that is permanent. Latent intelligence is present in every human being with different levels of development. Quantum teaching learning is different from other learning. These differences can be seen from the learning process which is more concerned with the elements of interpersonal intelligence of the students. Interpersonal intelligence shows students' ability to communicate effectively, are able to empathize well, and the ability to develop harmonious relationships with others.

On the basis of the above problems, the authors are interested in studying and want to conduct research on the influence of learning models and interpersonal intelligence on the economic learning outcomes of class X Dwiwarna High School.

\section{LITERATURE SURVEY}

According to Bloom (2009: 25), there are three domains of learning outcomes, namely: (1) Affective domain, which is an aspect related to feelings, emotions, attitudes, degrees of acceptance or rejection of an object, (2) Realm psychomotor, an aspect that relates to the ability to do work involving the limbs, the ability associated with physical gestures, (3) domains of cognitive an aspect relating to the ability, the ability to acquire knowledge, skills related to the acquisition of knowledge , recognition, understanding, conceptualization, determined and reasoning. Gagne (1985: 27) states that learning outcomes can be defined as the capacity or ability that can be obtained from the learning process that can be grouped into five category, namely: (1) intellectual skills, (2) verbal information, (3) a cognitive model, (4) motor skills, (5) attitudes, while Reigeluth (1983: 20) says that learning outcomes in general can be categorized into 3 indicators, namely (1) learning effectiveness, which is usually measured by students' success rates from various angles ; (2) learning efficiency, which is usually measured from study time and learning costs, and (3) the attractiveness of learning which is always measured by the tendency of students to want to learn continuously.

Samuelson (2003: 4) states that Economics as a scientific discipline is a way that humans do with their groups that utilizeresourcesmsum-marrowto become commodities (production), then distribute them to the public for consumption. According to Samuelson economics is the study of ways - ways that people take to use scarce resources to produce commodities or goods that are useful and distribute them to everyone. Dominick (2004: 4) defines economics as a social science that studies individuals and organizations involved in the production, consumption, and distribution of goods and services. Mill (2000: 89) defines economics as a practical science and expenditure, Smith (2005: 5) interpret the economy as investigating about the causes and circumstances of a country's wealth. So it can be concluded that economics is the knowledge that dominates how humans can fulfill their life needs related to the production, distribution and consumption of goods and services. In that sense, it shows a condition that refers to human activities in an effort to fulfill their life needs and achieve a desire, especially in an effort to be able to process the resources that exist in the surrounding environment, as a means of fulfilling life needs.

Gerlach and Ely (1980: 15) suggests that Learning Models are ways chosen to convey learning methods in certain learning environments. Next they describe that the intended Learning Model covers the nature, scope, and sequence of learning activities that can provide learning experiences to students. While Kemp (1995: 54) explains that Learning Model is a learning activity that must be done by teachers and students so that learning objectives can be achieved effectively and efficiently. Then Dick and Carey (2005: 30) also mention that Learning Model is a set of material and learning procedures that are used together - to achieve student learning outcomes.

According to Wena (2013: 160) the model Quantum Teaching is a new way that facilitates the learning process, which combines elements of art and directed achievement for all subjects by combining learning features into a form of teaching planning that will boost student achievement. In line with De Poter's opinion (2005: 8-9) the model quantum teaching is a lively change of learning with all its nuances that includes all the links, interactions, and differences that maximize learning moments and focus on dynamic relationships in the interaction classroom environment that sets the foundation in order to learn. The quantum learning model (Quantum Teaching) is divided into two categories, namely context and content. Context categories include (1) a supportive environment; (2) an empowering atmosphere; (3) solid foundation; and (4) dynamic learning design. Whereas in the content category include (1) prime presentation; (2) flexible facilities; (3) learning skills for learning; and (4) life skills. 
Learning quantum or Quantum Teaching have common characteristics that can solidify and strengthen the figures. According to Hamdayama (2013: 71) some general characteristics that appear to form a quantum learning figure or Quantum Teaching are as follows: (a). The model Quantum Teaching stems from cognitive psychology, not quantum physics; (b) The model Quantum Teaching is more humanistic, not positive-empirical, animalistic, and nativistic; (c) The model Quantum Teaching is more constructive in nature, not positivistic-empirical, behavioristic, and naturationalistic; (d) The model Quantum Teaching seeks to integrate (integrate), synergize, and collaborate the potential factors of human beings as learners with the environment (physical and mental) as a learning context; (e)models Quantum teaching focus on quality and meaningful interactions, not just meaning transactions; (f) The model Quantum Teaching emphasizes the acceleration of learning with a high level of success; (g) The Model Quantum Teaching emphasizes the naturalness and reasonableness of the learning process, not the artificiality or the artificial state; (h) The Model Quantum Teaching emphasizes the meaningfulness and necessity of the learning process; (i) The model Quantum Teaching integrates the context and content of learning; (j) The model Quantum Teaching focuses on forming academic skills, life skills, physical or material achievements; (k) The Model Quantum Teaching places values and beliefs as an important part of the learning process; (l) The model Quantum Teaching prioritizes diversity and freedom, not uniformity and order; (m) The model Quantum Teaching integrates the totality of body and mind in the learning process.

\section{EXPERIMENTAL WORK}

This study uses a method (quasi-experimental quasi-experiment) by conducting experiments in the class that are available as they are and do not make changes to the classroom situation and class schedule. Experiments carried out on economic learning using the quantum teaching learning model compared with the learning model Inquiry Based Learning carried out in the experimental class that has been determined with each class consisting of two groups of students who have high interpersonal intelligence and low interpersonal intelligence.

The design of this study is factorial $2 \times 2$, which is to find out the differences in economic learning outcomes of students taught by quantum teaching learning models and economic learning outcomes of students taught with learning models Inquiry Based Learning in terms of high interpersonal intelligence and low interpersonal intelligence as moderator variables. The independent variable of this study is the learning model, while the dependent variable of the study is the learning outcomes of Economics on material Understanding economic problems in relation to human needs, scarcity and economic systems. as in Table 2.

Table 2. Experimental design

\begin{tabular}{|l|c|c|}
\hline & $\begin{array}{c}\text { Learning Model } \\
\text { Luantum Teaching } \\
\text { Intelligence } \\
\text { Interpersonal }\end{array}$ & $\begin{array}{c}\text { Learning Model } \\
\text { Inquiry Based } \\
\text { Learning }\end{array}$ \\
\hline Height $\left(\mathrm{B}_{1}\right)$ & $\mathrm{A}_{1} \mathrm{~B}_{1}$ & $\left.\mathrm{~A}_{2}\right)$ \\
\hline Low $\left(\mathrm{B}_{2}\right)$ & $\mathrm{A}_{1} \mathrm{~B}_{2}$ & $\mathrm{~A}_{2} \mathrm{~B}_{1}$ \\
\hline
\end{tabular}

Analysis is the process of compiling data so that it can be interpreted. Sugiyono (2009: 333) explains that data analysis is the process of finding and compiling a systematic data obtained from interviews, field notes, documentation, by organizing data into categories, describing into units, synthesizing, arranging patterns, and choosing which important and to be learned, and make conclusions so that they are easy to understand.

The data analysis technique used in this study was descriptive and inferential statistical techniques. Descriptive statistical techniques were used to describe data, including: mean, median, mode, standard deviation (SD) and data trends. Inferential statistical techniques are used to test the research hypothesis, where the inferential technique to be used is the two-line Variant Analilis technique ( $2 \times 2$ factorial design) at the 0.05 significance level (Sudjana, 2002). Before the two-lane ANAVA is carried out, the analysis requirements test is carried out first, namely the normality test using the speaker test, and the homogeneity requirement test using the Fisher Test $(\mathrm{F})$ and the Bartlett test.

After testing the analysis requirements, then testing of 2-way ANAVA. If there is interaction between the learning model and the interpersonal intelligence of students, then a further test is held. This further test is carried out by the Scheffe Test, because the number of samples for each cell is not the same (n different). For hypothesis testing the statistical hypothesis is formulated as follows:

a. The first hypothesis is

$\mathrm{H}_{\mathrm{o}}: \mathrm{A}_{1} \leq \mathrm{A}_{2}$

$\mathrm{H}_{\mathrm{a}}: \mathrm{A}_{1}>\mathrm{A}_{2}$

b. The second hypothesis is

$\mathrm{H}_{\mathrm{o}}: \mathrm{B}_{1} \leq \mathrm{B}_{2}$

$\mathrm{H}_{\mathrm{a}}: \mathrm{B}_{1}>\mu \mathrm{B}_{2}$ 


\section{RESULT AND DISCUSSION}

\subsection{Result}

The data in this study were taken from 60 students from 2 study sample classes. The experimental class consists of 30 students who are treated with the learning model Quantum Teaching. The control class consisted of 30 students who were treated with the learning model Inquiry Based Learning. The two research sample classes are distinguished by their interpersonal intelligence, which is high interpersonal intelligence and low interpersonal intelligence. The data analysis used in this study is descriptive statistical analysis and inferential statistical analysis.

Testing is done by using a two-lane variance analysis test. The summary of data calculation for the two-way variance analysis test can be seen in the following table:

Table 3. Summary of research data calculation by ANOVA two lanes

\begin{tabular}{|c|c|c|c|c|c|}
\hline \multirow{2}{*}{\multicolumn{2}{|c|}{ Variable }} & & \multicolumn{2}{|c|}{ Model Learning } & \multirow[b]{2}{*}{ Total } \\
\hline & & & $\begin{array}{l}\text { Quantum } \\
\text { Teaching }\end{array}$ & $\begin{array}{l}\text { Inquiry Based } \\
\text { Learning }\end{array}$ & \\
\hline \multirow{8}{*}{$\begin{array}{l}\text { Interper } \\
\text { sonal } \\
\text { intellige } \\
\text { nce }\end{array}$} & \multirow{4}{*}{ High } & $\mathrm{N}$ & 15 & 15 & 30 \\
\hline & & $\Sigma X$ & 1299 & 1096 & 2395 \\
\hline & & $\Sigma \mathrm{X}^{2}$ & 112787 & 80508 & 193295 \\
\hline & & $\overline{\mathrm{x}}$ & 86,60 & 73.07 & 79,83 \\
\hline & \multirow{4}{*}{ Low } & $\mathrm{N}$ & 15 & 15 & 30 \\
\hline & & $\Sigma X$ & 978 & 848 & 1826 \\
\hline & & $\sum \mathrm{X}^{2}$ & 64544 & 48444 & 112988 \\
\hline & & $\overline{\mathrm{X}}$ & 65.20 & 56.53 & 60.87 \\
\hline \multirow{4}{*}{\multicolumn{2}{|c|}{ Total }} & $\mathrm{N}$ & 30 & 30 & 60 \\
\hline & & $\Sigma X$ & 2277 & 1944 & 4221 \\
\hline & & $\Sigma \mathrm{X}^{2}$ & 177331 & 128952 & 306283 \\
\hline & & $\overline{\mathrm{X}}$ & 75.90 & 64.80 & 70.35 \\
\hline
\end{tabular}

After the data above was analyzed using analysis of variance in two paths, a summary of the results of data calculation in the table was obtained. the following:

Table 4. Summary of calculation results of variance analysis of two lines

\begin{tabular}{|l|c|c|c|c|c|}
\hline Source of variance & JK & DK & RJK & F count & Ftable \\
\hline Inter-column & 1848.15 & 1 & 1848.15 & 51,679 & 4.01 \\
between lines & 5396.02 & 1 & 5396.02 & 150,887 & 4,01 \\
$\begin{array}{l}\text { Interaction } \\
\text { between }\end{array}$ & 88.82 & 1 & 88.82 & 2,484 & 4.01 \\
\hline In the group & 2002.67 & 56 & 35.76 & & \\
\hline Total & & 59 & & & \\
\hline
\end{tabular}

\subsection{Discussion}

The research variable consisted of independent and bound variables. The variables in this study include 3 variables, namely two independent variables and one dependent variable. The dependent variable is the economic learning outcomes of students, while the independent variable is composed of independent treatment variables, namely the learning model and the second independent variable namely interpersonal intelligence as a moderator variable. In order to avoid misinterpretation of the definition of variables used in this study, the operational definitions of variables are limited as follows:

a. Economic learning outcomes are abilities achieved by students as an illustration of students' cognitive abilities expressed in the form of test scores conducted after the learning process based on the subject of understanding economic problems in relation to human needs and understanding economic concepts in relation to consumer economic activities and producers based on the Syllabus High School Education Unit 
b. Based learning model Quantum Teaching is a learning plan directed which makes the nuances of learning fun by integrating elements of art, giving rise to dynamic learning interactions so that students can reconstruct the information and knowledge they obtain. The teacher's role in learning is more of a facilitator in order to encourage students to be actively involved in learning activities. The steps in learning Quantum Teaching are: (a) growing, (b) natural, (c) naming, (d) demonstration, (e) repeat, and (f) celebrate.

c. The Inquiry Based Learning model is a learning model that leads to the delivery of the content of lessons to students directly built on student questions. Students are encouraged to collaborate in solving problems, rather than just receiving instructions directly from the teacher. The teacher's job in this question-based learning environment is not to provide knowledge, but to help students go through the process of discovering the knowledge they seek for themselves. The teacher functions as a facilitator and not a source of answers. Sumantri (1999: 164) states that the method of inquiry is a method presentation of lessons that provide opportunities for students to find information with or without teacher assistance. Sagala (2009: 69) identifies several principles in the approach from the old way to the new method as follows; (a) Application of straightforward and planned principles of teaching and learning; (b) Referring to development aspects according to the level of students; (c) In the learning process respecting individual students; (d) Noting the condition of the objective objective of the individual on the personal development of students; (e) Using teaching methods and techniques that are in accordance with the subject matter; (f) Describe the concept of the problem in full discipline; (g) Using standard learning measurements and evaluations to measure learning abilities; (h) Use of audio visual equipment by utilizing the facilities and equipment that are available optimally.

d. Interpersonal intelligence is the ability to understand others and appear in the ability to interact well with others. In short, interpersonal intelligence is how humans can understand each other which also influences how they communicate. Thus, the characteristics of interpersonal intelligence to be measured in this study are: (a) empathy, (b) leadership, (c) sensitivity, (d) socialization.

\section{CONCLUSSION}

Based on the results and discussion of research in chapter IV, there are several conclusions that are answers to the questions posed in the formulation of the problem, namely:

1. Learning outcomes of students' economic learning in understanding Narrative texts taught by the learning model Quantum Teaching better than participant's students taught with Learning models Inquiry Based Learning. It can be seen from the analysis of data obtained in which the value $F_{\text {hitung }}=51,679 F_{\text {hitung }}=51,679$ while the value $F_{\text {tabel }}=4,01$ $F_{\text {tabel }}=4,01 F_{\text {so }} F_{\text {hitung }}>F_{\text {tabel }} F_{\text {hitung }}>F_{\text {tabel }}$ as.

2. Learning Outcomes Economic Learning Students who have high Interpersonal Intelligence are better than economic learning outcomes of students who are low interpersonal intelligence. It can be seen from the analysis of data obtained in which the value $F_{\text {hitung }}=150,887 F_{\text {hitung }}=150,887$ while the value $F_{\text {tabel }}=4,01 F_{\text {tabel }}=4,01$ so $F_{\text {hitung }}>F_{\text {tabel }}$ $F_{\text {hitung }}>F_{\text {tabel }}$ as.

3. There is no interaction of factors in the learning model Quantum Teaching and Inquiry Based Learning and Interpersonal Intelligence of students (high and low) in influencing the learning outcomes of Economics learning. It can be seen from the analysis of data obtained in which the value $F_{\text {hitung }}=2,48 F_{\text {hitung }}=2,48$ while the value $F_{\text {tabel }}=4,01 F_{\text {tabel }}=4,01$ so $F_{\text {hitung }}<F_{\text {tabel }} F_{\text {hitung }}<F_{\text {tabel }}$ as.

\section{REFERENCES}

[1] Adi M. Gunawan, Born To Be Genius. 2005, Jakarta: Gramedia Pustaka Utama.

[2] Dick and Carey, The Systematic Design of Instruction. 2006, New York: Wesley Education.

[3] Goleman, Daniel, Social Intellegence. 2007, Jakarta: Gramedia Pustaka Utama.

[4] Gardner, Rc., The Attitude/Motivation Test Battery, 2004, Technical Report.

[5] Kemp,Jerol E., The Instructional Design Process. 1995, New York: Harper \& Row Publisher.

[6] Matthews, Alan, et al, At The Chalk Face: Practical Techniques in Language Teaching, 1985, Edward Arnold.

[7] Reigeluth, Instructional Theories in Action, Hilsdale, New Jersey-Hove and London, 1987, Lawrence Erlboum, Associates, Publisher.

[8] S Bloom, Benjamin, Taxonomy of Education, Objectives, 1994, Affective Domain London: Longman Group.

[9] T.Safaria, Interpersonal Intelligence, 2005, Yogyakarta: Amara Books.

[10] Wimmer, R.D \& Dominick J.R.,(2011). Mass Media Research: An Introduction Ninth Edition. 2011, Boston: Wadsworth Cengage Learning. 